\title{
MODEL PENDIDIKAN TOLERANSI \\ DI PESANTREN MODERN DAN SALAF
}

Ali Maksum

(Dosen Fakultas Tarbiyah dan Kependidikan UIN Sunan Ampel

Surabaya)

\section{Abstract}

This research purposes to examine tolerant education model in both modern and salafis pesantren. This qualitatively descriptive study involves two pesantren settings, the modern pesantren Gontor Ponorogo and the salafis pesantren Tebuireng Jombang. Data is collected through interviews and documentations. From an inductive analysis, this research shows the following results. First, the Gontor modern pesantren acculturate preserved traditional value of pesantren in the modernity of educational systems. Particular teaching methods such as wetonan and sorogan are transformed into more standardized grades in classical way. Classic curriculum is still preserved in the class with some adaptations. This system is later called Mu'allimin or more popular as Kulliyatul-Mu'allimin al-Islamiyah (KMI). On the other hand, educational system in the pesantren of Tebuireng cannot be considered as the pure salafis category as the pesantren is still conducted the salafis education and the modern one separately. Therefore, the Tebuireng is now more exactly called "mixed pesantren" or integrated pesantren -between the khalafis and salafis. The next result of this result shows the fact that both salafis and integrated pesantrens actualize inclusive, peaceful, flexible, ad moderate Islam in which diversity and multiculturalism is in it. Islamic missionary in this way sustain Islam to live together with multi-culture. Curriculum of education and good-model leadership create santris with high tolerance.

Keywords: Tolerance Education, Modern Pesantren, and Salafis Pesantren. 


\section{Abstrak}

Penelitian ini bertujuan mengetahui model pendidikan toleransi di pesantren modern dan di pesantren salaf. Penelitian ini merupakan penelitian deskriptif kualitatif dengan setting dua pesantren, yakni pesantren modern Gontor Ponorogo dan pesantren salaf Tebuireng Jombang. Teknik pengumpulan datanya dengan wawancara dan dokumentasi. Untuk analisis data digunakan teknik analisis induktif. Hasil penelitian menunjukkan: (1) Pesantren Darussalam Gontor merupakan pesantren modern, dengan ciri khas berupaya memadukan tradisionalitas dan modernitas pendidikan. Sistem pengajaran wetonan dan sorogan diganti dengan sistem klasikal (pengajaran di dalam kelas) yang berjenjang dan kurikulum terpadu diadopsi dengan penyesuaian tertentu. Sistem pendidikan yang digunakan di pondok modern dinamakan sistem Mu'allimin, atau terkenal dengan nama KulliyatulMu'allimin al-Islamiyah (KMI). Sedangkan sistem pendidikaan di pondok pesantren Tebuireng, dilihat dari segi sistem pendidikan dan pengajarannya sepenuhnya tidak dapat disebut sebagai pesantren salaf murni. Karena di pesantren Tebuireng masih mempertahankan sistem pendidikan salaf, juga menerapkan sistem pendidikan modern. Oleh karena itu, untuk sekarang ini lebih tepat apabila menyebut Pondok Pesantren Tebuireng dengan sebutan Pondok Pesantren Campuran atau Pondok Pesantren Terpadu (antara khalaf dan salaf). (2) Baik di pondok pesantren modern dan salaf, Islam yang dipahami dan diaktualkan adalah Islam yang inklusif, ramah, tidak kaku, moderat, yakni Islam yang bernuansa perbedaan dan sarat dengan nilai-nilai multikultural. Mendakwahkan Islam yang seperti inilah yang menjadikan Islam bisa bersentuhan dengan multikultur. Untuk membentuk santri yang toleran kedua pesantren ini mengajarkannya melalui kurikulum pendidikan dan keteladanan hidup sehari-hari.

Kata Kunci: Pendidikan Toleransi, Pesantren Modern, dan Pesantren Salaf. 


\section{A. Pendahuluan}

Dalam konteks Indonesia, pendidikan toleransi, pendidikan yang dapat mencetak peserta didik mempunyai kearifan lokal, atau menghasilkan peserta didik yang berpandangan inklusif, penting untuk diwujudkan. Indonesia, melebihi kebanyakan negara-negara lain, merupakan negara yang tidak saja multisuku, etnik dan agama, tetapi juga multibudaya. Kemajemukan tersebut pada satu sisi merupakan kekuatan sosial dan keragaman yang indah apabila satu sama lain bersinergi dan saling bekerja sama untuk membangun bangsa. Namun, pada sisi lain, kemajemukan tersebut apabila tidak dikelola dan dibina dengan tepat dan baik akan menjadi pemicu dan penyulut konflik dan kekerasan yang dapat menggoyahkan sendisendi kehidupan berbangsa. Peristiwa Ambon dan Poso, misalnya, merupakan contoh kekerasan dan konflik horizontal yang telah menguras energi dan merugikan tidak saja jiwa dan materi tetapi juga mengorbankan keharmonisan antar sesama masyarakat Indonesia. ${ }^{1}$

Semenjak reformasi digulirkan, diskursus pluralisme dan multikulturalisme di negeri ini terus mengemuka dan berkembang pesat. Terkait dengan masalah tersebut sikap hidup toleran menjadi penting. Toleransi dipandang bisa menjadi perekat baru integrasi bangsa yang sekian lama tercabik-cabik. Integrasi nasional yang selama ini dibangun berdasarkan politik kebudayaan lebih cenderung seragam dianggap tidak lagi relevan dengan kondisi dan semangat demokrasi global. Desentralisasi kekuasaan dalam bentuk otonomi daerah semenjak 1999 adalah jawaban bagi tuntutan demokrasi tersebut. Namun, desentralisasi sebagai keputusan politik nasional ternyata kemudian disadari tidak begitu produktif apabila dilihat dari kacamata integrasi nasional suatu bangsa besar yang isinya beraneka ragam suku bangsa, etnis, agama, dan status sosial. ${ }^{2}$

\footnotetext{
1 Martin Van Bruinessen, "Genealogies of Islamic Radicalism in post-Suharto Indonesia", Southeast Asia Research, No. 2, 2002, 117.

2 Ali Maksum, Pluralisme dan Multikulturalisme: Paradigma Baru Pendidikan Agama Islam di Indonesia (Malang: Aditya Media, 2011), 1.
} 
Berbicara tentang pendidikan Islam, pesantren merupakan jenis institusi pendidikan Islam tertua dan telah lama berakar di dalam budaya masyarakat Indonesia. Pesantren merupakan pusat pengkajian dan pendalaman khazanah ilmu-ilmu keislaman dan sekaligus sebagai pusat gerakan dakwah penyebaran agama Islam di masyarakat. Pesantren juga dikenal sebagai penjaga ortodoksi Islam. Pondok pesantren merupakan lembaga pendidikan yang unik, tidak saja karena keberadaannya yang sudah sangat lama, tetapi juga karena kultur, metode, dan jaringan yang diterapkan oleh lembaga agama tersebut. ${ }^{3}$ Selain itu pondok pesantren juga sebagai sistem pendidikan yang asli (indegenious) di Indonesia. ${ }^{4}$

Penelitian ini berhasil mengetahui dua hal pokok: (1) Sistem pendidikan di Pesantren Modern Gontor Ponorogo dan Pesantren Salaf Tebuireng Jombang; (2) Pelaksanaan pembelajaran toleransi di pesantren modern Gontor Ponorogo dan pesantren salaf Tebuireng Jombang. Penelitian ini tidak hanya menghasilkan pengetahuan deskriptif dan fenomenologis, tetapi memberikan kontribusi akademis berupa peningkatan pengetahuan perilaku inklusif, demokratis, dan toleran. Di samping itu, penelitian ini memberikan kontribusi praktis bagi usaha-usaha untuk melakukan pendidikan inklusif dan demokratis di lembaga pendidikan pondok pesantren.

\section{B. Kerangka Teoritik}

\section{Tipologi Pesantren}

Secara etimologis, "pesantren" berasal dari pe-santri-an yang berarti tempat santri; asrama tempat santri belajar agama; atau pondok. Dikatakan pula, pesantren berasal dari kata santri, yaitu seorang yang belajar agama Islam, dengan demikian

3 Syafruddin Amir, Pesantren Pembangkit Moral Bangsa.(Online) (http:// www.pikiran-

rakyat.com/cetak/2006/072006/03/11wacana01.htm-28k-, diakses tanggal 5 April 2012).

${ }^{4}$ Abd. Mustaqim,. "Menggagas Pesantren Transformatif", Aula, No. 09 Tahun XXV, September 2003, 76.

Jurnal Pendidikan Agama Islam Volume 03, Nomor 01, Mei 2015

Hal 84-108 
pesantren mempunyai arti tempat orang berkumpul untuk belajar agama Islam. ${ }^{5}$

Sementara itu, secara terminologis, pondok pesantren merupakan institusi sosial keagamaan yang menjadi wahana pendidikan bagi umat Islam yang ingin mendalami ilmu-ilmu keagamaan. Pondok pesantren dalam terminologi keagamaan merupakan institusi pendidikan Islam, namun demikian pesantren mempunyai icon sosial yang memiliki pranata sosial di masyarakat. Hal ini karena pondok pesantren memiliki modalitas sosial yang khas, yaitu: 1) ketokohan kyai, 2) santri, 3) independent dan mandiri, dan 4) jaringan sosial yang kuat antar alumni pondok pesantren. ${ }^{6}$

Kegiatan utama yang dilakukan dalam pesantren adalah pengajaran dan pendidikan Islam. Hal ini menuntut kualitas seorang kyai tidak sekedar sebagai seorang ahli tentang pengetahuan keislaman yang mumpuni, tetapi juga sebagai seorang tokoh panutan untuk diteladani dan diikuti. Melalui kegiatan ajar-belajar, seorang kyai mengajarkan pengetahuan keislaman tradisional kepada para santrinya yang akan meneruskan proses penyebaran Islam tradidional.

Para ahli pendidikan, mengklasifikasi jenis pesantren ke dalam dua tipologi; yakni pesantren modern, yang sudah banyak mengadopsi sistem pendidikan sekolah modern Barat dan pesantren salaf, yang berorientasi pada pelestarian tradisi dengan sistem pendidikan tradisional.

Pertama, Pondok pesantren modern, merupakan pengembangan tipe pesantren karena orientasi belajarnya cenderung mengadopsi seluruh sistem belajar secara klasik dan meninggalkan sistem belajar tradisional. Penerapan sistem belajar modern ini terutama nampak pada penggunaan kelas-

5 Zamakhsyari Dhofier, Tradisi Pesantren: Studi tentang Pandangan Hidup Kyai (Jakarta: LP3S, 1983), 18.

${ }^{6}$ A. Rafiq Zainul Mun'im, “Peran Pesantren dalam Education For All di Era Globalisasi", (2009) dalam http://ejournal.sunan-ampel.ac.id/index.php/JPI/ article/view/177/ 162, diakses 23 Nopember 2013. 
kelas belajar baik dalam bentuk madrasah maupun sekolah. Kurikulum yang dipakai adalah kurikulum sekolah atau madrasah yang berlaku secara nasional. Santrinya ada yang menetap ada yang tersebar di sekitar desa lokasi pesantren. Kedudukan para kyai sebagai koordinator pelaksana proses belajar mengajar dan sebagai pengajar langsung di kelas. Perbedaannya dengan sekolah dan madrasah terletak pada porsi pendidikan agama dan bahasa Arab lebih menonjol sebagai kurikulum lokal. ${ }^{7}$

Kedua, pesantren Salaf. Menurut Zamakhsyari Dhofier, ada beberapa ciri pesantren salaf atau tradisional, terutama dalam hal sistem pengajaran dan materi yang diajarkan. Pengajaran kitabkitab Islam klasik atau sering disebut dengan kitab kuning karena kertasnya berwarna kuning, terutama karangan-karangan ulama yang menganut faham Syafi"iyah, merupakan pengajaran formal yang diberikan dalam lingkungan pesantren tradisional. Keseluruhan kitab-kitab klasik yang diajarkan di pesantren dapat digolongkan ke dalam delapan kelompok, yaitu nahwu (syntax) dan shorof (morfologi), fiqh, usul fiqh, hadis, tafsir, tauhid, tasawuf dan etika, dan cabang-cabang lain seperti tarikh dan balaghah. ${ }^{8}$

\section{Sistem Pendidikan Pesantren}

Secara umum Pondok Pesantren didefinisikan sebagai lembaga pendidikan yang memiliki lima elemen pokok; (1) Pondok/Asrama: adalah tempat tinggal bagi para santri. Pondok inilah yang menjadi ciri khas dan tradisi pondok pesantren dan membedakannya dengan sistem pendidikan lain yang berkembang di Indonesia, (2) Masjid: Merupakan tempat untuk mendidik para santri terutama dalam praktik seperti shalat, pengajian kitab klasik, pengkaderan kyai, dan lain-lain, (3) Pengajaran kitab-kitab klasik: Merupakan tujuan utama pendidikan di pondok pesantren, (4) Santri: Merupakan sebutan

7http://qidal.wordpress.com/2012/03/28/pondok-pesantren-karakteristikdan-fungsinya/, diakses 12 Desember 2013.

${ }^{8}$ Zamakhsyari Dhofier, Tradisi Pesantren.

Jurnal Pendidikan Agama Islam Volume 03, Nomor 01, Mei 2015

Hal 86-108 
untuk siswa/murid yang belajar di pondok pesantren, dan (5) Kyai: merupakan pimpinan pondok pesantren. Kata kyai sendiri adalah gelar yang diberikan masyarakat kepada seorang ahli agama Islam yang menjadi pimpinan pesantren dan mengajarkan kitab-kitab klasik. ${ }^{9}$

Kegiatan utama yang dilakukan dalam pesantren adalah pengajaran dan pendidikan Islam. Hal ini menuntut kualitas seorang kyai tidak sekedar sebagai seoarang ahli tentang pengetahuan keislaman yang mumpuni, tetapi juga sebagai seorang tokoh panutan untuk diteladani dan diikuti. Melalui kegiatan ajar-belajar, seorang kyai mengajarkan pengetahuan keislaman tradisional kepada para santrinya yang akan meneruskan proses penyebaran Islam tradisional.

Di dalam pesantren proses pendidikan dan pengajaran bisa berlangsung dalam dua bentuk: sistem klasikal dan berjenjang dan sistem tradisional, seperti sorogan, wetonan, dan bandongan. Menurut Mustofa Bisri di samping ciri lahiriah tersebut, masih ada cirri umum yang menandai karakteristik pesantren, yaitu kemandirian dan ketaatan santri kepada kyai yang sering diinisiasi sebagai pengkultusan. Meski mempunyai tipologi umum yang sama, pesantren juga sangat ditentukan karakternya oleh kyai yang memimpinnya. Sebagai pendiri dan "pemilik" pesantren (terutama pesantren salaf) dalam menentukan corak pesantrennya, pastilah tidak terlepas dari karakter dan kecenderungan pribadinya. 10

\section{Islam dan Toleransi Beragama}

Al-Qur'an menjelaskan bahwa pluralitas adalah salah satu kenyataan objektif komunitas umat manusia, sejenis hukum Allah atau Sunnah Allah, dan bahwa hanya Allah yang tahu dan dapat menjelaskan, di hari akhir nanti, mengapa manusia berbeda satu

${ }^{9}$ Ibid.

${ }_{10}$ Mustofa Bisri, "Pesantren dan Pendidikan”, Tebuireng, Edisi 1/Tahun I/JuliSeptember 2007, 12. 
dari yang lain, dan mengapa jalan manusia berbeda-beda dalam beragama. Dalam al-Qura'an disebutkan, yang artinya: "Untuk masing-masing dari kamu (umat manusia) telah kami tetapkan Hukum (Syari'ah) dan jalan hidup (minhaj). Jika Tuhan menghendaki, maka tentulah Dia jadikan kamu sekalian umat yang tunggal (monolitik). Namun Dia jadikan kamu sekalian berkenaan dengan hal-hal yang telah dikaruniakan kepada kamu. Maka berlombalah kamu sekalian untuk berbagai kebajikan. Kepada Allah-lah tempat kalian semua kembali; maka Dia akan menjelaskan kepadamu sekalian tentang perkara yang pernah kamu perselisihkan" (QS. 5: 48).

Dalam kaitan langsung dengan prinsip inilah Allah, di dalam Alquran, menegur keras Nabi Muhammad SAW ketika dia menunjukkan keinginan dan kesediaan yang menggebu untuk memaksa manusia menerima dan mengikuti ajaran yang disampaikanya, sebagai berikut: "Jika Tuhanmu menghendaki, maka tentunya manusia yang ada di muka bumi ini akan beriman. Maka apakah kamu hendak memaksa manusia, di luar kesediaan mereka sendiri? (QS. 10: 99).

Demikianlah beberapa prinsip dasar Al-Qur'an yang berkaitan dengan masalah pluralisme dan toleransi. Paling tidak, dalan dataran konseptual, Al-Qur'an telah memberi resep atau arahan-arahan yang sangat diperlukan bagi manusia Muslim untuk memecahkan masalah kemanusiaan universal, yaitu realitas pluralitas keberagamaan manusia dan menuntut supaya bersikap toleransi terhadap kenyataan tersebut demi tercapainya perdamaian di muka bumi. Karena Islam menilai bahwa syarat untuk membuat keharmonisan adalah pengakuan terhadap komponen-komponen yang secara alamiah berbeda.

Selain itu, era sekarang adalah era multikulturalisme dan pluralisme, yang dimana seluruh masyarakat dengan segala unsurnya dituntut untuk saling tergantung dan menanggung nasib secara bersama-sama demi terciptanya perdamaian abadi. Salah satu bagian penting dari konsekuensi tata kehidupan global yang ditandai kemajemukan etnis, budaya, dan agama tersebut, 
adalah membangun dan menumbuhkan kembali teologi pluralisme dalam masyarakat.

Demi tujuan itu, maka pendidikan sebenarnya masih dianggap sebagai instrumen penting. Sebab, "pendidikan" sampai sekarang masih diyakini mempunyai peran besar dalam membentuk karakter individu-individu yang dididiknya, dan mampu menjadi "guiding light" bagi generasi muda penerus bangsa. Dalam konteks inilah, pendidikan agama sebagai media penyadaran umat perlu membangun teologi inklusif dan pluralis, demi harmonisasi agama-agama (yang telah menjadi kebutuhan masyarakat agama sekarang).

Apalagi, kalau mencermati pernyataan yang telah disampaikan oleh Alex R. Rodger (1982) bahwa "pendidikan agama merupakan bagian integral dari pendidikan pada umumnya dan berfungsi untuk membantu perkembangan pengertian yang dibutuhkan bagi orang-orang yang berbeda iman, sekaligus juga untuk memperkuat ortodoksi keimanan bagi mereka". Artinya pendidikan agama adalah sebagai wahana untuk mengeksplorasi sifat dasar keyakinan agama di dalam proses pendidikan dan secara khusus mempertanyakan adanya bagian dari pendidikan keimanan dalam masyarakat. Pendidikan agama dengan begitu, seharusnya mampu merefleksikan persoalan pluralisme, dengan mentransmisikan nilai-nilai yang dapat menumbuhkan sikap toleran, terbuka dan kebebasan dalam diri generasi muda. ${ }^{11}$

Melalui pengembangan kurikulum pendidikan agama Islam berbasis kemajemukan dengan mempertimbangkan pengembangan komponen, bahan, metode, peserta didik, media, lingkungan, dan sumber belajar. Maksud dan tujuan pendidikan pluralisme-multikulturalisme, dengan begitu akan dapat dijadikan sebagai jawaban atau solusi alternatif bagi keinginan untuk merespon persoalan-persoalan di atas. Sebab dalam

11 Alex R. Rodger, Educational and Faithin Open Society (Britain: The Handel, 1982), 61. 
pendidikannya, pemahaman Islam yang hendak dikembangkan oleh pendidikan berbasis pluralisme-multikulturalisme adalah pemahaman dan pemikiran yang bersifat inklusif.

\section{Pendidikan dan Toleransi}

Relasi harmonis antar-umat beragama seringkali menuai masalah tatkala masing-masing pihak bersikukuh dengan kebenaran agama yang dianutnya, dengan memaksakan agamanya kepada yang lain. Dalam konteks ini, Islam melalui alQur'an dengan tegas menolak setiap orang beriman untuk memaksakan agamanya kepada orang lain. Bahkan, al-Qur'an menjamin kebebasan beragama kepada manusia. Sebagaimana diungkapkan dalam firman Allah SWT: "Tidak ada paksaan untuk (memasuki) agama (Islam). Sesungguhnya telah jelas jalan yang benar daripada jalan yang sesat. Karena itu, barangsiapa yang ingkar kepada Thaghut dan beriman kepada Allah, maka sesungguhnya ia telah berpegang kepada buhul tali yang amat kuat yang tidak akan putus. Dan Allah Maha Mendengar lagi Maha Mengetahui" (Q.S. Al-Baqarah: 256).

Orang beriman juga harus mampu menahan diri untuk tidak melakukan kekerasan, misalnya, memaksakan iman kepada orang lain dengan paksaan fisik, atau dengan paksaan lain, seperti tekanan sosial, bujukan harta benda atau kedudukan, atau caracara lain yang bersifat politis dan tidak berkeadilan/berkeadaban. Mereka harus berusaha dengan jalan ruhani, dan biarlah Tuhan yang menentukan sesuai dengan kehendak-Nya (Abdullah Yusuf Ali, Jilid I: 510).

Untuk itu, sikap toleran dan tidak boleh ada paksaan dalam beragama meniscayakan penyebaran agama secara santun dan sopan. Mengajak orang untuk beragama, baik kepada orang yang seagama maupun kepada orang yang berlainan agama, harus dilakukan dengan sebaik-baiknya ajakan dan penuh hikmah (Q.S. Al-Nahl/16: 125). Bahkan, Al-Qur'an secara tegas melarang umatberagama berbantah-bantahan mengenai Tuhan (Allah) dengan para penganut kitab suci lain karena, para penganut kitab suci itu 
meski berbeda-beda tetapi sesungguhnya mereka menyembah Allah yang Maha Esa. Allah SWT menegaskan itu dalam firmanNya: Artinya: "Apakah kamu memperdebatkan dengan kami tentang Allah, padahal Dia adalah Tuhan kami dan Tuhan kamu; bagi kami amalan kami, bagi kamu amalan kamu dan hanya kepada-Nya kami mengikhlaskan hati" (Q.S. Al-Baqarah: 139).

Shihab menafsirkan bahwa ayat ini menunjukkan tidak diperkenankannya para pemeluk agama untuk mengklaim dirinya paling benar. Ayat ini tidak memersalahkan siapa-siapa, dan tidak juga mengklaim kebenaran untuk siapa-siapa. Oleh karena itu, cara berpikir umat-beragama yang biasanya hitam putih: agama kitalah yang benar, yang absah, dan satu-satunya jalan keselamatan dari Tuhan; agama lain adalah salah, palsu, menyesatkan, dan masuk neraka, haruslah ditampik. Sebab, ketika perang klaim kebenaran (truth claim) dan janji keselamatan dicuatkan, maka tidak saja meletupkan keberagamaan yang eksklusif, tapi juga akan melahirkan suasana saling curiga-dalam sebagian kasus menjadi konflik kekerasan-antar-umat beragama atas nama Tuhan.

Pendidikan formal mempunyai tugas untuk mempertahankan nilai-nilai dan budaya nusantara dari derasnya perkembangan teknologi dari Negara-Negara maju. Artinya, pendidikan kita harus tetap mempertahankan tradisi akademik yang kokoh. Yang merupakan bukti eksistensinya terjaga dalam menjaga keaslian iklim akademik. Pendidikan harus tetap menjaga dan melestarikan lima aspek dalam membentuk peserta didik (Rusli, 1985: 129), yaitu, 1) dimensi intelektual; 2) dimensi kultural; 3) dimensi nilai-nilai transendental; 4) dimensi keterampilan fisik/jasmani; 5) dimensi pembinaan kepribadian manusia sendiri.

Kenyataannya, lembaga pendidikan sering mengabaikan kelima aspek di atas, pada akhirnya menyebabkan hilangnya peran proses persemaian nilai-nilai dan budaya kesantunan dan religiusitas yang inklusif. Upaya menciptakan dinamika peradaban manusia yang berbasis ragam merupakan keniscayaan 
bagi suatu negara berkembang. Arah pengembangannya tidak boleh kontra produktif dengan nilai-nilai dasar keagamaan dan budaya Timur. Kehidupan masyarakat mengutamakan gaya hidup bebas dan budaya pesta. Hal ini agar tidak terjadi krisis intelektual dan moral manusia. Apalagi kehidupan global, langsung maupun tidak langsung, berpengaruh terhadap nilainilai kehidupan masyarakat maupun bangsa. Pendidikan merupakan cagar budaya dan sistem sosial berpengaruh membentuk kepribadian dan interaksi sosialnya.

Pendidikan toleransi, dalam perspektif Islam, tidak dapat dilepaskan dengan konsep pluralitas, sehingga muncul istilah Pendidikan Islam Pluralis-Multikultural. Konstruksi pendidikan semacam ini berorientasi pada proses penyadaran yang berwawasan pluralitas secara agama, sekaligus berwawasan multikultural. Dalam kerangka yang lebih jauh, konstruksi pendidikan Islam pluralis-multikultural dapat diposisikan sebagai bagian dari upaya secara komprehensif dan sistematis untuk mencegah dan menanggulangi konflik etnis agama, radikalisme agama, separatisme, dan integrasi bangsa. Nilai dasar dari konsep pendidikan ini adalah toleransi. ${ }^{12}$

Islam inklusif adalah paham keberagamaan yang didasarkan pada pandangan bahwa agama-agama lain yang ada di dunia ini sebagai yang mengandung kebenaran dan dapat memberikan manfaat serta keselamatan bagi penganutnya. Di samping itu, ia tidak semata-mata menunjukkan pada kenyataan tentang adanya kemajemukan, melainkan keterlibatan aktif terhadap kenyataan kemajemukan. Sebaliknya, eksklusif merupakan sikap yang memandang bahwa keyakinan, pandangan, pikiran, dan prinsip diri sendirilah yang paling benar, sementara keyakinan, pandangan, pikiran, dan prinsip yang dianut orang lain adalah salah, sesat, dan harus dijauhi. ${ }^{13}$

12 Ngainun Naim dan Achmad Sauqi, Pendidikan Multikultural: Konsep dan Aplikasi (Yogyakarta: Ar-Ruzz Media, 2008).

13 Ade Wijdan SZ. Dkk., Pemikiran dan Peradaban Islam (Yogyakarta: Safiria Insania Press, 2007).

Jurnal Pendidikan Agama Islam Volume 03, Nomor 01, Mei 2015

Hal 92-108 
Masyarakat Islam tradisional identik dengan masyarakat NU (Nahdlatul Ulama) yang tentu saja tidak dapat dilepaskan dari pesantren "salaf" sebagai rujukan praktik beragama. Sikap golongan Islam tradisional yang diwakili NU, pada dasarnya tidak terlepas dari akidah Ahlusunnah waljama'ah (Aswaja) yang dapat disebut paham moderat. ${ }^{14}$ Pemikiran Aswaja sangat toleransi terhadap pluralisme pemikiran. Berbagai pikiran yang tumbuh dalam masyarakat muslim mendapatkan pengakuan yang apresiatif. Dalam hal ini Aswaja sangat responsif terhadap hasil pemikiran berbagai madzhab, bukan saja yang masih eksis di tengah-tengah masyarakat (Madzhab Hanafi, Maliki, Syafi'i, dan Hanbali), melainkan juga terhadap madzhab-madzhab yang pernah lahir, seperti imam Daud al-Zhahiri, Imam Abdurrahman al-Auza'i, Imam Sufyan al-Tsauri, dan lain-lain. ${ }^{15}$

\section{Metode Penelitian}

Penelitian ini merupakan penelitian deskriptif kualitatif, karena bermaksud menggambarkan, mengungkap, dan menjelaskan model pendidikan toleransi di pesantren modern dan salaf, yang diketahui produknya telah menjadi manusia yang memegang nilainilai multikultural. Demikian pula dinamakan penelitian deskriptif, karena bertujuan membuat gambaran mengenai situasi atau kejadian. ${ }^{16}$ Selain itu, tujuan deskriptif adalah untuk membantu pembaca mengetahui apa yang terjadi di lingkungan di bawah pengamatan, seperti apa pandangan partisipan yang berada di latar penelitian, dan seperti apa aktivitas yang terjadi di latar penelitian. ${ }^{17}$

14 Mujamil Qomar, NU Liberal; Dari Tradisionalisme Ahlussunnah ke Universalisme Islam (Bandung: Mizan, 2002), 62.

${ }^{15}$ Husein Muhammad, "Memahami Sejarah Ahlussunnah Waljamaah: Yang Toleran dan Anti Ekstrem", dalam Imam Baehaqi (ed.), Kontroversi Aswaja (Yogyakarta: LKiS, 1999), 40.

${ }_{16}$ Mohammad Nazir, Metode Penelitian (Bogor: Ghalia Indonesia, 2005), 55.

17 Emzir, Metodologi Penelitian Pendidikan Kuantitatif dan Kualitatif (Jakarta: Rajawali Pers, 2008), 175. 
Subjek penelitian adalah para alumni pesantren Gontor Ponorogo dan alumni Pesantren Tebu Ireng Jombang. Subjek merupakan sumber informasi potensial yang bisa memberikan dan memperkaya informasi tentang pokok masalah yang menjadi pusat perhatian penelitian.

Data diperoleh dengan cara wawancara mendalam (indept interview) dan sumber dokumentasi. Wawancara mendalam dilakukan dengan berpatokan pada interview guide, yakni daftar pertanyaan yang sifatnya terbuka dan ingin memperoleh jawaban mendalam. Sementara sumber dokumentasi digunakan untuk memperoleh informasi yang berkaitan dengan data-data sekunder mengenai sistem pendidikan dan penanaman sikap toleransi proses pendidikan di pesantren. Dokumen yang dimaksud adalah sumber pustaka buku, hasil penelitian terdahulu, dan sumber-sumber internet.

Analisis data menunjuk pada kegiatan mengorganisasikan data ke dalam susunan-susunan tertentu dalam rangka penginterpretasian data. Data ditabulasi sesuai dengan susunan sajian data yang dibutuhkan untuk menjawab masing-masing masalah dan/atau hipotesis penelitian, kemudian diinterpretasikan atau disimpulkan, baik untuk masing-masing masalah atau hipotesis penelitian maupun untuk keseluruhan masalah yang diteliti. ${ }^{18}$ Teknik analisis data yang digunakan dalam penelitian ini adalah teknik analisis induktif, yaitu analisis yang bertolak dari data dan bermuara pada simpulan-simpulan umum. Kesimpulan umum itu bisa berupa kategorisasi maupun proposisi. ${ }^{19}$

\section{Hasil Penelitian dan Pembahasan}

\section{Sistem Pendidikan di Pesantren Modern dan Salaf}

Pesantren Gontor terkenal sebagai pesantren modern pertama di Indonesia. Ciri khas pesantren modern berupaya

18 Sanapiah Faisal, Format-format Penelitian Sosial (Jakarta: Raja Grafindo Persada, 2001), 34.

${ }^{19}$ Burhan Bungin, Metode Penelitian Kualitatif: Aktualisasi Metodologis ke Arah Varian Kontemporer (Jakarta: Raja Grafindo Persada, 2001), 209. 
memadukan tradisionalitas dan modernitas pendidikan. Sistem pengajaran formal ala klasikal (pengajaran di dalam kelas) dan kurikulum terpadu diadopsi dengan penyesuaian tertentu. Dikotomi ilmu agama dan umum juga dieliminasi. Kedua bidang ilmu ini sama-sama diajarkan, namun dengan proporsi pendidikan agama lebih mendominasi. Sistem pendidikan yang digunakan di pondok modern dinamakan sistem Mu'allimin. Dalam konteks ini di pesantren Gontor terkenal dengan nama Kulliyatul-Mu'allimin al-Islamiyah (KMI).

KMI membagi pendidikan formalnya dalam perjenjangan yang sudah diterapkan sejak tahun 1936. KMI memiliki program reguler dan program intensif.

a. Program reguler untuk lulusan Sekolah Dasar (SD) / Madrasah Ibtidaiyah (MI) dengan masa belajar hingga enam tahun. Kelas I-III setingkat dengan pendidikan Sekolah Menengah Pertama (SMP) / Madrasah Tsanawiyah (MTs) jika mengacu pada kurikulum nasional dan kelas IV-VI setara dengan Sekolah Menengah Atas / Madrasah Aliyah (MA).

b. Program intensif KMI untuk lulusan SMP / MTs yang ditempuh dalam 4 tahun.

c. Untuk Perguruan Tinggi, pesantren Gontor pada tanggal 17 Nopember 1963 mendirikan PT dengan nama Perguruan Tinggi Darussalam (PTD). Nama PTD ini kemudian berganti menjadi Institut Pendidikan Darussalam (IPD) yang selanjutnya berganti menjadi Institut Studi Islam Darussalam (ISID). Sejak tahun 1996 ISID telah memiliki kampus tersendiri di Demangan, Siman, Ponorogo.

Selain jenjang program pendidikan di atas, pesantren modern Gontor juga mempunyai sistem pendidikan yang excellent untuk menjaga mutu pendidikannya, yaitu:

a. Bahasa Arab dan bahasa Inggris ditetapkan sebagai bahasa pergaulan dan bahasa pengantar pendidikan, kecuali mata pelajaran tertentu yang harus disampaikan dengan Bahasa Indonesia. Bahasa Arab dimaksudkan agar santri memiliki dasar kuat untuk belajar agama mengingat dasar-dasar hukum 
Islam ditulis dalam bahasa Arab. Bahasa Inggris merupakan alat untuk mempelajari ilmu pengetahuan / umum.

b. Pengasuhan santri adalah bidang yang menangani kegiatan ekstrakurikuler dan kurikuler. Setiap siswa wajib untuk menjadi guru untuk kegiatan pengasuhan pada saat kelas $\mathrm{V}$ dan VI jika ingin melanjutkan ke jenjang perguruan tinggi di ISID, mereka tidak akan dipungut biaya, tetapi wajib mengajar kelas I-VI di luar jam kuliah. Mengajar kuliah dan membantu pondok itulah yang di lakukan sebagai bentuk pengabdian dan pengembangan diri.

c. Pelatihan tambahan bagi guru dengan materi yang sesuai dengan standar pendidikan nasional.

d. Keterampilan, kesenian, Kepramukaan dan olahraga tidak masuk kedalam kurikulum tetapi menjadi aktivitas ekstrakurikuler.

e. Siswa diajarkan untuk bersosialisasi dengan membentuk masyarakat sendiri di dalam pondok, melalui organ organisasi. Mulai dari ketua asrama, ketua kelas, ketua kelompok, organisasi intra/ ekstra, hingga ketua regu pramuka. Sedikitnya ada 1.500 jabatan ketua yang selalu berputar setiap pertengahan tahun atau setiap tahun.

Sementara itu, pondok pesantren Tebuireng telah beberapa kali melakukan perubahan kebijaksanaan yang berkaitan dengan pendidikan. Sebagaimana umumnya pesantren, sistem pengajaran yang digunakan adalah metode sorogan (santri membaca sendiri materi pelajaran kitab kuning di hadapan guru), metode wetonan atau bandongan ataupun halaqah (kyai membaca kitab dan santri memberi makna). Semua bentuk pengajaran tidak dibedakan dalam jenjang kelas. Kenaikan tingkat pendidikan dinyatakan dengan bergantinya kitab yang khatam (selesai) dikaji dan diikuti santri. Materi pelajarannya pun khusus berkisar tentang pengetahuan agama Islam, ilmu syari'at dan bahasa Arab. Inilah sesungguhnya misi utama berdirinya pondok pesantren. 
Perubahan sistem pendidikan di pesantren ini pertama kali diadakan Kyai Hasyim Asy'ari pada tahun 1919 M. yakni dengan penerapan sistem madrasi (klasikal) dengan mendirikan Madrasah Salafiyah Syafi'iyah. Sistem pengajaran disajikan secara berjenjang dalam dua tingkat, yakni Shifir Awal dan Shifir Tsani.

Hingga pada tahun 1929 M. kembali dirintis pembaharuan, yakni dengan dimasukkannya pelajaran umum ke dalam struktur kurikulum pengajaran. Satu bentuk yang belum pernah ditempuh oleh pesantren manapun pada waktu itu. Dalam perjalanan penyelenggaraan madrasah ini berjalan lancar. Namun demikian bukan tidak ada tantangan, karena sempat muncul reaksi dari para wali santri -bahkan- para ulama' dari pesantren lain. Hal demikian dapat dimaklumi mengingat pelajaran umum saat itu dianggap sebagai kemunkaran, budaya Belanda dan semacamnya. Hingga banyak wali santri yang memindahkan putranya ke pondok lain. Namun madrasah ini berjalan terus, karena disadari bahwa ini pada saatnya nanti ilmu umum akan sangat diperlukan bagi para lulusan pesantren.

Kini, pondok Pesantren Tebuireng telah berumur lebih dari 1 abad. Dinamika pun menyertainya seiring dengan perjalanan pesantren ini, dari pergantian kepemimpinan (pengasuh), kebijakan, pembangunan sarana prasarana, jumlah santri, dan sampai sistem pendidikan. Saat ini santri Tebuireng mencapai kurang lebih 2000 orang yang berasal dari berbagai daerah, baik Jawa maupun luar Jawa. Hanya saja, santri yang berasal dari Jawa lebih banyak dibanding luar Jawa yang kira-kira hanya lima pesennya.

Pondok Pesantren Tebuireng yang pada awal berdirinya adalah bertipe salaf, dalam dinamikanya dan untuk sekarang ini tidak lagi dapat disebut dengan Pondok Pesantren Salaf sama sekali. Akan tetapi, pesantren ini di samping masih mempertahankan sistem pendidikan salaf, dengan mengikuti perkembangan zaman, menerapkan juga sistem pendidikan modern. Oleh karena itu, untuk sekarang ini lebih tepat apabila menyebut Pondok Pesantren Tebuireng dengan sebutan Pondok 
Pesantren Campuran atau Pondok Pesantren Terpadu (antara khalaf dan salaf).

Sistem campuran ini dapat dilihat, misalnya untuk yang salaf, model pengajaran dengan sistem sorogan dan bandongan masih diterapkan, demikian pula dengan masih adanya pengajaran terhadap kitab-kitab kuning (kitab salaf). Sementara itu, sistem khalaf atau modern dapat dilihat bahwa Pondok Pesantren Tebuireng telah menerapkan sistem klasikal (berkelaskelas atau berjenjang) dan bentuk pendidikan madrasah (sekolah modern). Sistem modern dapat dilihat pula dari segi kurikulumnya (mengadopsi Depag dan Diknas) yang disediakan atau metode pengajarannya.

Adapun jenjang-jenjang pendidikan umum yang ada di dalam pesantren Tebuireng sebagai berikut: a). Madrasah Tsanawiyah Salafiyah Syafi'iyyah; b). Madrasah Aliyah Salafiyah Syafi'iyyah; c). SMP A. Wahid Hasyim (Sekolah Standar Nasional); d). SMA A. Wahid Hasyim; e). Madrasah Muallimin; dan f). Ma'had 'Aly.

\section{Model Pendidikan Toleransi di Pesantren Modern dan Salaf}

Dalam konteks pondok modern Gontor, pendidikan berwawasan toleransi sesungguhnya telah menjadi pendidikan dasar yang tidak hanya diajarkan dalam pengajar formal di kelas saja. Tapi juga dilakukan dalam kehidupan sehari-hari santri. Pendidikan formal toleransi diwujudkan dalam bentuk pengajaran materi keindonesiaan / kewarganegaraan yang telah dikurikulumkan. Sistem pengajaran di pondok modern yang didominasi bahasa asing (Arab dan Inggris) sebagai pengantar, tidak melunturkan semangat pendidikan toleransi anak didik (santri). Karena materi ini ditempatkan sebagai materi primer dan harus diajarkan dengan medium bahasa Indonesia pula.

Dalam bidang non formal, pesantren dengan kelebihan pendidikan intens 24 jamnya, memiliki banyak waktu untuk menyisipkan aneka pendidikan. Salah satunya wawasan toleransi. Pola umum yang nyaris diberlakukan di berbagai pondok modern 
adalah sistem pendidikan toleransi dan multikultur yang menyatu dalam aturan dan disiplin pondok. Salah satunya dalam urusan penempatan pemondokan (asrama) santri. Di pondok modern, tidak diberlakukan penempatan permanen santri di sebuah asrama. Dalam arti, seluruh santri harus mengalami perpindahan sistematis ke asrama lain, guna menumbuhkan jiwa sosial mereka terhadap keragaman.

Dalam hal ini Amir Maliki, seorang alumni pesantren Gontor mengatakan bahwa:

“ ... Untuk menumbuhkan sikap toleransi dan pemahaman terhadap budaya lain, dalam satu kamar ditempatkan para santri yang berasal dari berbagai daerah, baik Jawa, luar Jawa, dan bahkan santri dari luar negeri. Penempatan santri dalam satu kamar ini tidak permanen. Pondok Modern Gontor menetapkan regulasi agar setiap tahun santri diharuskan mengalami perpindahan asrama. Setiap satu semester mereka juga akan mengalami perpindahan antarkamar dalam asrama yang mereka huni. Hal ini ditujukan untuk memberi variasi kehidupan bagi para santri, juga menuntun mereka memperluas pergaulan dan membuka wawasan mereka terhadap aneka tradisi dan budaya santri-santri lainnya. Penempatan santri tidak didasarkan pada daerah asal atau suku. Bahkan, penempatan telah diatur sedemikian rupa oleh pengasuh pondok, dan secara maksimal diupayakan kecilnya kemungkinan santri-santri dari daerah tertentu menempati sebuah kamar yang sama. Dengan demikian antara santri tidak berpikir primordial dan hanya mengenal temantemannya yang satu daerah saja. Dengan sistem ini para santri mempunyai wawasan multikultural dan toleransi melalui pengalaman nyata sehari-hari." 20

Ketentuan yang diberlakukan, satu kamar maksimal tidak boleh dihuni oleh tiga orang lebih santri asal satu daerah. Menurut Dr. KH Abdullah Syukri Zarkasyi, upaya ini untuk

20 Amir Maliki (Alumni Pesantren Gontor), Wawancara pada 20 Nopember 2013. 
melebur semangat kedaerahan mereka ke dalam semangat yang lebih universal. Di samping itu, agar santri juga dapat belajar kehidupan bermasyarakat yang lebih luas, berskala nasional, bahkan internasional bersama para santri mancanegara. ${ }^{21}$ Namun, penerapan pola pendidikan ini, menurut Syukri Zarkasyi, tidak berarti menafikan unsur daerah. Karena unsur kedaerahan telah diakomodir dalam kegiatan daerah yang disebut "konsulat", yang ketentuan organisasi dan kegiatannya telah diatur, khususnya untuk diarahkan menolaknya menjadi sumber fanatisme kedaerahan.

Pendidikan toleransi lainnya dalam intensitas pendidikan pondok modern adalah diberlakukannya aturan mengikat yang melarang santri berbicara menggunakan bahasa daerah. Selain bahasa utama Arab dan Inggris, ketika masuk lingkungan pondok santri hanya dibolehkan berbicara bahasa Indonesia dalam beberapa kesempatan dan kepentingan. Pendisiplinan santri dalam pendidikan multikulturalisme lewat bahasa ini sangat ketat. Bagi santri yang melanggarnya akan diberi hukuman bervariasi yang edukatif. Pendidikan toleransi atas perbedaan juga kental diajarkan dalam sistem pendidikan pondok modern. Keberagaman pemikiran dan ijtihad diajarkan kepada santri tanpa pemaksaan, atau mengajarkan mereka untuk memaksakan ide. Sikap toleransi terhadap perbedaan pendapat sangat diunggulkan sistem pendidikan pondok modern.

Dengan sistem Mu'allimin yang didukung intensitas pendidikan 24 jam, beban pengejawantahan Kurikulum Berbasis Kompetensi (KBK), seperti disyaratkan dalam pendidikan formal, dapat dilalui pondok modern. Pada KBK, kendala utamanya adalah keterbatasan waktu ajar untuk memberi pemahaman penuh sebuah materi kepada siswa. Dengan sistem Mu'allimin, masa pendidikan luar kelas di pondok pesantren cenderung lebih banyak dibanding waktu formal pembelajaran di dalam kelas.

${ }^{21}$ KH. Abdullah Syukri Zarkasyi, Manajemen Pesantren: Pengalaman Pondok Modern Gontor (Ponorogo: Trimurti Press, 2005), 125.

Jurnal Pendidikan Agama Islam Volume 03, Nomor 01, Mei 2015

Hal 100-108 
Keterbatasan masa pengajaran di kelas ini pun dapat tertanggulangi pondok pesantren dengan adanya banyak waktu luang yang dapat dimanfaatkan para guru untuk melengkapi pengajaran kepada santri. Pola ini sangat mengefisiensikan waktu dan membuat pengajaran menjadi efektif. Ditambah lagi dengan arus utama sistem pendidikan di pondok modern yang tidak mengenal dikotomi pendidikan ekstrakulikuler dan intrakulikuler. ${ }^{22}$

Keutamaan pendidikan toleransi di pondok modern juga tercermin dari muatan/isi kurikulum yang kentara mengajarkan wawasan santri akan keragaman keyakinan. Dalam kelompok bidang studi Dirasah Islamiyah, sebagai contoh, diajarkan materi khusus Muqaranat al-Adyan (Perbandingan Agama) yang konten luasnya memaparkan sejarah, doktrin, isme, fenomena dan dinamika keagamaan di dunia. Materi ini sangat substansial dalam pendidikan multikulturalisme, karena santri diberi wawasan berbagai perbedaan mendasar keyakinan agama mereka (Islam) dengan agama-agama lain di dunia. Materi ini sangat potensial membangun kesadaran toleransi keragaman keyakinan yang akan para santri temui saat hidup bermasyarakat kelak.

Dalam pendidikan sikap multikulturalistik, pondok modern menerapkan pemberian wawasan rutin melalui visualisasi aneka kultur dan budaya para santrinya. Setiap tahun ajaran baru digelar seremoni besar Khutbatul 'Arsy dengan salah satu materi acara berupa pertunjukan aneka kreasi dan kreativitas pelangi budaya semua elemen santri, berdasarkan kategori "konsulat" (kedaerahan). Dalam acara ini dilombakan demontrasi keunikan khazanah dan budaya tempat domisili asal santri. Semua santri diwajibkan terlibat dalam kegiatan ini. Kegiatan pembuka tahun ajaran baru ini ditujukan untuk menjadi pencerah awal dan

22 Ibid., 155. Didukung oleh hasil wawancara dengan alumni, diantaranya dengan Nur Fuad pada tanggal 18 Nopember 2013. 
wawasan kebhinekaan budaya dalam lingkungan yang akan mereka huni.

Sementara itu, di pesantren Tebuireng, pendidikan toleransi di sekolah formal yang ada di lingkungan Pondok Pesantren Tebuireng, santri secara langsung memperoleh pendidikan multikultural setelah mereka belajar PKN atau Moral Pancasila. Tentu saja, mata pelajaran ini akan membawa siswa terhadap kesadaran berbangsa dan bernegara dalam bingkai Indonesia. Mata pelajaran ini akan mengantarkan siwa menjadi manusia Indonesia yang ramah, toleran, moderat, dan dapat besikap adil. Intinya, bahwa mata pelajaran ini menjadikan siswa dapat memahami nilai-nilai Pancasila dan mengamalkannya.

Demikian pula, secara langsung santri mendapat pendidikan multikultural setelah mereka mengikuti pengajian kitab-kitab salaf (kuning) yang diajarkan di Pesantren Tebuireng. Secara khusus, ada satu kitab yang dapat membentuk karakter santri yang moderat atau mengantarkan santri berpaham dalam Islam dengan paham yang tidak ekstrim, yaitu Kitab Risalah Ahlis Sunnah Wal Jama'ah. Kitab ini tentu akan membekali santri berpaham Ahlussunnah Wal Jama'ah. Sementara diketahui, bahwa paham keagamaan yang dikenal Ahlussunnah Wal Jama'ah (Aswaja) memiliki ciri-ciri mengedepankan sikap toleran, moderat, sikap adil.

Selanjutnya, pendidikan multikultural diperoleh santri Pondok Pesantren Tebuireng secara tidak langsung dari tradisi yang sekarang ini ada dan dikembangkan di lingkungan Tebuireng. Misalnya, dari pengasuh yang sekarang, yaitu K.H. Salahuddin Wahid, santri secara tidak langsung dapat meneladani model, gaya, karakter, pemikiran, dan model ber-Islam beliau. Dikatakan, bahwa pengasuh yang sekarang, K.H. Salahuddin Wahid tampak dalam kepemimpinannya bersikap demokratis, menghormati pendapat santri, dan bahkan dalam banyak hal pendapat para pengurus-lah yang dijadikan sebagai pijakan kebijakan. 
Akhmad Halim mengemukakan, "Kepemimpinan Gus Solah (panggilan akrab K.H. Salahuddin Wahid) bersifat demokratis, efektif, dan rasional, karena semua kebijakan merupakan hasil musyawarah. Kelebihan pada pemimpin-pemimpin di Pesantren Tebuireng sebelumnya banyak diwariskan kepadanya, meskipun basis pendidikannya bersifat umum, namun tidak mengurangi kemampuannya untuk mengelola pesantren sebagai amanat berat yang diembannya". 23

Diyakini pula, apabila para santri dapat meneladani K.H. Salahuddin Wahid dalam sikap dan pemikirannya, maka akan menjadi manusia yang berpandangan luas, dapat membawa Islam sebagai ajaran rahmatun lil'lamiin, berpaham Islam yang moderat, inklusif, dan intinya menjadi santri yang telah memahami dan menjiwai nilai-nilai multikultural. Secara tidak langsung santri Tebuireng juga telah belajar berpikir, berpandangan luas, dan berjiwa demokratis ketika budaya diskusi dan dialog telah berjalan. Ada beberapa forum diskusi sebagai pembelajaran santri yang telah berjalan di lingkungan Pondok Pesantren Tebuireng, diantaranya Forum Bahtsul Masail, Fordislaf (Forum Diskusi Santri Salaf), Forum Diskusi Mahasiswa S1 yang membahas permasalahan sekitar tafsir dan penafsirannya dan juga pemikiran Islam, dan Forum Diskusi Mahasiswa S2.

Diskusi semacam ini tentu dapat menjadikan pembelajaran bagi santri agar dapat berisikap demokratis dan menghargai pendapat orang lain. Dapat dilihat, ketika diskusi berjalan tentu akan muncul beragam pendapat dan pandangan, baik dari peserta diskusi sendiri maupun referensi yang digunakan. Diketahui bahwa dalam paham Islam yang dipegang santri, yaitu Ahlussunnah Wal Jama'ah, dinyatakan mengakui eksistensi empat mazhab dalam fiqih, sehingga bukan tidak mungkin muncul perbedaan dalam menyikapi satu kasus dengan referensi dari berbagai mazhab.

${ }^{23}$ Akhmad Halim, Wawancara pada 21 Nopember 2013. 


\section{E. Kesimpulan}

Pesantren Darussalam Gontor merupakan pesantren modern pertama di Indonesia. Ciri khas pesantren modern berupaya memadukan tradisionalitas dan modernitas pendidikan. Sistem pengajaran wetonan dan sorogan diganti dengan sistem klasikal (pengajaran di dalam kelas) yang berjenjang dan kurikulum terpadu diadopsi dengan penyesuaian tertentu. Dikotomi ilmu agama dan umum juga dieleminasi. Kedua bidang ilmu ini sama-sama diajarkan, namun dengan proporsi pendidikan agama lebih mendominasi. Sistem pendidikan yang digunakan di pondok modern dinamakan sistem Mu'allimin, atau terkenal dengan nama Kulliyatul-Mu'allimin al-Islamiyah (KMI). Sedangkan sistem pendidikaan di pondok pesantren Tebuireng, dilihat dari segi sistem pendidikan dan pengajarannya sepenuhnya tidak dapat disebut sebagai pesantren salaf murni. Pondok Pesantren Tebuireng yang pada awal berdirinya adalah bertipe salaf, dalam dinamikanya dan untuk sekarang ini tidak lagi dapat disebut dengan Pondok Pesantren Salaf sama sekali. Dalam perkembangannya, pesantren ini telah banyak melakukan inovasi sistem pendidikan dan pengajarannya. Di samping masih mempertahankan sistem pendidikan salaf, dengan mengikuti perkembangan zaman, menerapkan juga sistem pendidikan modern. Oleh karena itu, untuk sekarang ini lebih tepat apabila menyebut Pondok Pesantren Tebuireng dengan sebutan Pondok Pesantren Campuran atau Pondok Pesantren Terpadu (antara khalaf dan salaf).

Pendidikan yang berwawasan toleransi secara prinsip telah diterapkan dalam sistem pendidikan pondok modern Gontor dan pondok salaf Tebuireng. Pendidikan ini telah tercakup dalam sistem formal kurikulum maupun proses pembelajaran sehari-hari. Dalam konteks pondok modern Gontor, pendidikan berwawasan toleransi diwujudkan dalam dua bentuk: (1) melalui kurikulum, yakni diwujudkan dalam bentuk pengajaran materi keindonesiaan / kewarganegaraan yang telah dikurikulumkan. (2) Dalam kehidupan sehari-hari, yakni sistem pendidikan toleransi dan multikultur yang menyatu dalam aturan dan disiplin pondok Penempatan santri dalam satu kamar ini tidak permanen, tetapi tiap semester atau satu 
tahun diadakan perpindahan antarakamar dan antarsantri. Sedangkan model pendidikan toleransi di pesantren salaf Tebuireng ditempuh dengan dua jalur: (1) Melalui kurikulum pendidikan dan pengajaran. Dalam pengajaran formal sekolah dan madrasah di lingkungan Tebuireng, pendidikan toleransi diberikan melalui materi pelajaran Pendidikan Kewarganegaraan dan Pancasila. Sementara di dalam pesantren sendiri, pendidikan toleransi dilangsungkan dengan mengikuti pengajian kitab-kitab salaf (kuning) yang diajarkan di Pesantren Tebuireng. (2) Melalui keteladanan kiai dalam kehidupan sehari-hari. Santri secara tidak langsung dapat meneladani model, gaya, karakter, pemikiran, dan model ber-Islam dari keteladanan para kyai pengasuh pesantren sebagai modelnya. Mulai dari KH. Hasyim Asy'ari, KH. Wahid Hasyim, KH. Yusuf Hasyim sampai KH. Shalahuddin Wahid merupakan figurfigur yang mmahami Islam secara inklusif, moderat, dan toleran. 


\section{DAFTAR PUSTAKA}

Amir, Syafruddin, 2006, "Pesantren Pembangkit Moral Bangsa".(Online) (http://www.pikiran-rakyat.com/cetak/2006/072006/03/

11wacana01.htm-28k-diakses tanggal 5 April 2012).

Bisri, Mustofa, 2007, "Pesantren dan Pendidikan", Tebuireng, Edisi 1/Tahun I/Juli-September.

Bruinessen, Martin Van, 2002, "Genealogies of Islamic Radicalism in post-Suharto Indonesia", Southeast Asia Research, No. 2.

Bungin, Burhan. 2001, Metode Penelitian Kualitatif: Aktualisasi Metodologis ke Arah Varian Kontemporer (Jakarta: Raja Grafindo Persada).

Dhofier, Zamakhsyari, 1983, Tradisi Pesantren: Studi tentang Pandangan Hidup Kyai (Jakarta: LP3ES).

Emzir, 2008, Metodologi Penelitian Pendidikan Kuantitatif dan Kualitatif (Jakarta: Rajawali Pers).

Faisal, Sanapiah, 2001, Format-format Penelitian Sosial (Jakarta: Raja Grafindo Persada).

http://qidal.wordpress.com/2012/03/28/pondok-pesantren-

karakteristik-dan-fungsinya/d diakses 12 Desember 2013.

Maksum, Ali, 2011, Pluralisme dan Multikulturalisme: Paradigma Baru Pendidikan Agama Islam di Indonesia (Malang: Aditya Media).

Muhammad, Husein, 1999, "Memahami Sejarah Ahlussunnah

Waljamaah: Yang Toleran dan Anti Ekstrem", dalam Imam Baehaqi (ed.), Kontroversi Aswaja (Yogyakarta: LKiS).

Mun'im, A. Rafiq Zainul, 2009, "Peran Pesantren dalam Education For All di Era Globalisasi", (2009) dalam http://ejournal.sunanampel.ac.id/ index.php/JPI/ article/view/177/ 162, diakses 23 Nopember 2013.

Mustaqim, Abd., 2003, "Menggagas Pesantren Transformatif", Aula, No. 09 Tahun XXV, September.

Naim, Ngainun dan Achmad Sauqi, 2008, Pendidikan Multikultural: Konsep dan Aplikasi (Yogyakarta: Ar-Ruzz Media).

Nazir, Mohammad, 2005, Metode Penelitian (Bogor: Ghalia Indonesia). 
Qomar, Mujamil, 2002, NU Liberal; Dari Tradisionalisme Ahlussunnah ke Universalisme Islam (Bandung: Mizan).

Rodger, Alex R., 1982, Educational and Faithin Open Society (Britain: The Handel).

Wijdan SZ., Ade, Dkk., 2007, Pemikiran dan Peradaban Islam (Yogyakarta: Safiria Insania Press).

Zarkasyi, KH. Abdullah Syukri, 2005, Manajemen Pesantren: Pengalaman Pondok Modern Gontor (Ponorogo: Trimurti Press).

\section{Responden:}

Amir Maliki (Alumni Pesantren Gontor), Wawancara pada 20 Nopember 2013.

Akhmad Halim, Wawancara pada 21 Nopember 2013.

Nur Fuad, Wawancara pada 18 Nopember 2013. 
Ali Maksum

Jurnal Pendidikan Agama Islam Volume 03, Nomor 01, Mei 2015

Hal 108-108 